\section{Symposium on Jewellery Manufacturing Technology, Santa Fe, USA}

\section{Leah Gal-Or}

Israel Institute of Metals, Technion City, 32000 Haifa, Israel

The second Santa Fe Symposium on Jewellery Manufacturing took place on 21-24 September 1988. It was organized by Dave Schneller of Vimar Corp., Boulder Co., and E. Bell of Rio Grande, Albuquerque, New Mexico. The main objectives of the Symposium, as stated by the organizers, were to provide a forum for the presentation to jewellery manufacturers of the results of research performed in academic and industrial institutions to promote scientific approaches to problem solving in this industry, and to encourage the exchange of experience and know-how among attendees. The lectures presented at the Symposium represent three aspects of jewellery manufacturing: raw materials, processes and safety.

The aspect of raw materials was dealt with in four papers presented by Dr. Ch. Raub and D. Ott from the Precious Metals Institute (F.E.M.) in Germany, and by researchers from Leach \& Garner Co. in the U.S. Dr. Raub discussed the historical development of jewellery alloys beginning with those used by ancient goldsmiths, through the recipes of a 12th century monk and up to modern alloys. His talk was based on papers published in Gold Bulletin from 1968 to 1987. J. Deroner and R. Carrano from Leach \& Gamer Co. presented their work on the effect of common additives ( $\mathrm{Si}, \mathrm{B}, \mathrm{Co}$ and $\mathrm{Ir}$ ) on the properties of two 14 carat castings alloys. The properties studied were form filling, strength, hardness, grain refining, surface roughness and porosity. D. P. Agarwal and G. Raykhtsaum also from Leach \& Garner, discussed the enhancement and measurement of colour in jewellery alloys. They presented the basic principles of quantitative colour measurement, the effects of various alloying additives on colour, the limits of the range of colours which could be achieved in 14 carat alloys, and showed how colour could be used as a measurable criterion in studies of tarnishing, heat treatment and phase composition. D. Ott presented a most detailed discussion of the properties of investment and of their testing. He discussed the effect of water content on setting time, strength, permeability and surface roughness of the investment. He also described methods used for measuring properties of the slurry (such as viscosity) as well as properties of the mould (such as strength and gas permeability).

A variety of jewellery manufacturing processes were discussed at the Symposium. Casting, the dominant process in jewellery production, was the subject of several lectures. D. Ott surveyed in detail the casting methods used, their principles, relative advantages and the effect of process variables on product quality. L. Diamond (private consultant) presented an original approach for determining the solidification time for various jewellery items. He applied the Chervanov equation and suggested that the area of an item could be determined by measuring the amount of nickel plated out on it as compared to the amount plated out under the same conditions on a known surface area. J. Nielsen from Polytechnic University New York, who has pioneered research on the casting of gold alloys for many years, discussed the application of controlled solidification in casting of jewellery. E. Bell of Rio Grande Co. presented his ideas on how to produce a temperature gradient in the casting flask for directional solidification. He also reported results on experiments on the heating and cooling characteristics of investment molds.

Sheet and wire production was discussed by W. Kilgore from James Avery Craftsman Inc. in a lecture entitled The Fabrication and
Quality Assurance of 14 Carat Gold and Sterling Silver Sheet and Wire for Jewellery Products. Kilgore emphasized the origins of defects likely to arise in the various production steps, and the related process control parameters.

The finishing of jewellery received considerable attention in papers dealing with electroplating, electropolishing, chemical polishing (bombing) and mass media finishing. Ch. Raub surveyed the early development of jewellery plating in the 19 th century, the importance of substrate surface quality, pretreatment, intermediate layers, and of electrolyte variables. He emphasized the need for specifications in jewellery plat ing, similar to those for precious metal plating in the field of electronics. The electropolishing of gold alloys was discussed by L. Gal-Or from the Center of Noble Metals in Israel. Applications in jewellery finishing, and advantages and disadvantages as compared with mechanical polishing were presented. Also, the mechanism, composition of solutions, and process variables were discussed.

D. Schneller from Vimar Corp. presented two lectures on chemical polishing (bombing) at room temperature. This process, widely practiced in the U.S., is based on a violent reaction between KCN and $\mathrm{H}_{2} \mathrm{O}_{2}$. In his first lecture, Schneller discussed the safety hazards of this process and the methods to counteract them. In his second lecture he analyzed the process variables such as $\mathrm{CN}^{-}$and $\mathrm{H}_{2} \mathrm{O}$ concentrations, $\mathrm{pH}$ and mixing procedures, and recommended rinsing stages. Mass media finishing was discussed in detail by $\mathrm{S}$. Nigro from Rio Grande $\mathrm{Co}$. He surveyed media types, shapes and sizes, explained the functions of compounds and considerations to be taken into account when selectiing equipment. He dwelt at length on the interrelationships between those variables.

Recovery of gold from cyanide solutions such as spent plating and bombing baths was discussed by L. GaI-Or. Mechanisms and kinetics of electrochemical and chemical deposition by dissolution of aluminium were presented. E. Salomon from Armbrust Chain Co lectured on An Economic Approach to Waste Minimization and Environmental Risk Reduction in Electroplating for the Jewellery Industry. He discussed ways to minimize waste based on efficient use of water, described waste disposal methods and reported studies on waste generation in 10 jewellery plants in Rhode Island.

Safety in jewellery manufacturing was one of the main subjects of the Symposium. J. Bellows from the California Department of Health Services presented $A$ Survey of Hazards in the Jewellery Industry. He enumerated the hazards in the various stages of jewellery production, which he considers a most hazardous industry. His talk was based on a survey conducted in 15 companies in the Los Angeles area during which air sampling, and interviews with workers and employers were performed. D. Schneller discussed cases of cyanide poisoning, available antidotes and safety ineasures to be taken. P. Pryor from the U.S. Public Health Service presented a talk on Silica Hazards and Safety Procedures in the Handling of Investment. He explained the conditions that lead to silicosis, and means for protection against it. He also presented the results of a study he had performed on the concentration of $\mathrm{SiO}_{2}$ in the air at different stages of investment handling.

An interesting lecture on Technology Transfer was presented by A. Tasker from the World Gold Council. He discussed the application of CAD-CAM in dentistry and its potential application to jewellery manufacturing. The lecture also included data on the properties and development of the $1 \%$ Ti-99\%Au alloy and an analysis of black dermographism (inclusion of metallic particles in the skin) as related to jewellery wear.

Proceedings of this Symposium will be published in the near future; tapes of the lectures are available as well as last year's proceedings from: Santa Fe Symposium, 6801 Washington N.E., Albuquerque, NM 87109. 